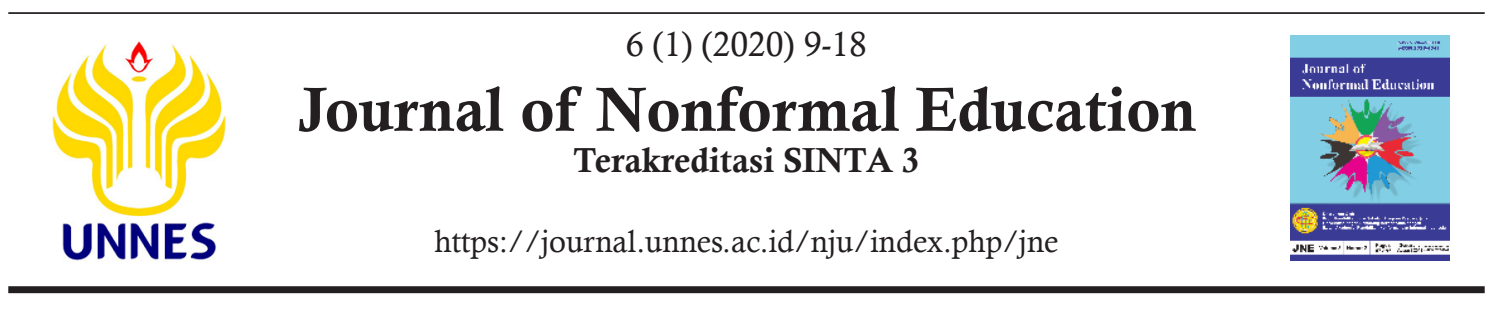

\title{
Implementation CIPP Evaluation \\ of Keaksaraan Usaha Mandiri Program
}

\author{
Andang Heryahya ${ }^{\bowtie}$, Bedjo Sujanto, Rugayah
}

DOI: http://dx.doi.org/10.15294/jne.v6i1.22624

Universitas Negeri Jakarta, Indonesia

\section{History Article}

Submitted 22 December 2019 Revised 24 January 2020 Accepted 4 February 2020

\section{Keywords}

illiteracy; family economic income; manual labor; dropouts; keaksaraan usaha mandiri

\begin{abstract}
The number of illiterate populations in 2019 aged 15-59 years was 3,474,694 people spread throughout the Regency/City in Indonesia. Since 2005 the government has published an independent business literacy program as part of efforts to eradicate illiteracy, poverty and ignorance. This study aims to determine the implementation of the program with the CIPP evaluation model. Using a qualitative approach with a case study method in six community education institutions in five sub-districts in Bogor Regency. Data obtained through interviews, observation and documentation. The results showed that the Kekasaraan Usaha Mandiri program was carried out in a dense, illiterate environment in rural and mountainous areas. The main cause of illiteracy is the low economic income of the family which has an impact on dropping out of school and a short way of thinking of the community, with the perception that the most important thing is to be able to make money even though you have to be a manual worker. Organizers have an understanding of the literacy education development as part of efforts to educate the nation's life. Educational literacy in the implementation of learning using product packaging and marketing materials that are not delivered optimally because the competency and entrepreneurial experience of the teacher is insufficient. Learning innovations that can integrate literacy education, business activities and religious education need to be done. Then it is necessary to improve entrepreneurship competencies for tutors, as well as collaborating with microfinance institutions or local entrepreneurs.
\end{abstract}

Correspondence Author:

E-mail: andang@tazkia.ac.id
p-ISSN 2442-532X

e-ISSN 2528-4541 


\section{INTRODUCTION}

Literacy is a major component in the process of human development, population growth and the economy. The importance of the initial level of adult literacy and the population growth. Functional Literacy has the function of developing basic human capabilities that include the ability to read, write and count functional in improving the quality and standard of living the society (Laksono, et al., 2018). Similarly short-term economic growth has a significant impact on the initial level of adult literacy, and the medium human development and low human development samples (Mazumdar, 2005).

Development will be achieved when unemployment, inequality, injustice and poverty can be overcome properly (Kolawole \& Ajila, 2015). Poverty can be seen from various dimensions, such as concern for children's health, infrastructure, employment opportunities and literacy levels (Adepoju \& Akinluyi, 2017). Illiterate rural members of community work as small farmers, laborers, sailors, and are the poor with very low income or earning level (Arbarini, et al., 2018). Literacy is the core of education and is important in realizing the welfare of the family, community and country, especially for developing countries.

Indonesia is part of a developing country with a population of 269 million (Badan Pusat Statistik, 2019). The total illiteracy population in 2019 was $8,621,798$ people spread throughout the Regency/City. While the number of poor people is $25,144.72$ million people out of a total population of $269,536,482$ people. In West Java Province there are 110,779 illiterate people aged 15-59 years. The largest number is in Bogor Regency with 18,820 people (Badan Pusat Statistik, 2019). If every year 1000 people are illiterate free, then it takes 18 years, assuming there are no new illiterate additions or return illiteracy. For this reason, since 2005 the Ministry of Education and Culture of the Republic of Indonesia has organized the Keaksaraan Usaha Mandiri (KUM) program. This program is a continuation of the Keaksaraan Dasar $(\mathrm{KD})$ program. The aim of the program is to improve literacy as well as the introduction of students' business ability. Oriented to the maintenance of reading, writing and arithmetic so as not to be illiterate again and able to participate more optimally in family and community life.

The Community Learning Activity Center (PKBM) is one of the institutions that organize various types of non-formal and informal educational activities (Rahma, 2019). The Community Learning Activity Center (PKBM) which is an educational institution that organizes various learning activities in accordance with the needs of the community with the aim of developing the abilities and skills of the community to be able to improve their quality of life (Istiqomah \& Articles, 2017). Institutions that carry out programs are community education units including the Community Learning Activity Center (PKBM), Learning Groups (Pokjar) and other similar education units. This program is carried out annually in all regencies/cities in Indonesia using funds from the government (Ministry of Education and Culture, 2017). The KUM program has been running for 14 years and no research has been conducted on the effectiveness of program implementation.

The Ministry of Education and Culture has only conducted internal monitoring and evaluation activities in several regions of the organizing agency. For this reason, comprehensive research needs to be carried out on all program components including context, input, process and product. Assess and interpret program effectiveness (Echols \& Shadily, 2000). Identify and gather information to help choose among alternative policy choices (Worthen \& Sanders, 1973). The information obtained is used as material for policy making on program effectiveness (Owen, 1993). Evaluations are used to provide advice and recommendations on accelerating the completion of illiteracy and poverty programs.

Evaluations are designed to provide recommendations to certain parties in making decisions. Conducted for decision-making purposes, whereas research is intended to build our general understanding and knowledge of a particular topic and to inform practice. In general, program evaluation examines programs to determine their worth and to make recommendations for programmatic refinement and success. Program evaluation is carried out to obtain information on the achievement of objectives using existing criteria. The significance of program evaluation lies in the process of knowing the level of program achievement, program performance and quality with predetermined criteria (Spaulding, 2008).

Evaluation is carried out to find out the benefits and to help policy makers understand the performance of the ongoing programs. In a broader sense, evaluation is said to be an activity of identifying, clarifying and applying criteria that can be maintained to assess an object. Criteria are one of the main things in evaluation activities. Program evaluation criteria in this study are program guides from the Ministry of Education and Culture, concepts and theories of literacy 
education as part of non-formal education.

Based on the background outlined above, the formulation of this research problem is how to implement the Keaksaraan Usaha Mandiri (KUM) program in Bogor Regency, Indonesia. This research can contribute to the development of literacy education in the future as part of efforts to educate the nation's life.

\section{METHODS}

This study uses the CIPP evaluation model, which includes evaluating the components of Context, Input, Process and Product (Stufflebeam \& Shinkfield, 1984). Context evaluation is carried out to determine the needs of the program including the potential that exists in an area. Input evaluation is carried out to obtain information about program resources. Process evaluation is used to determine the effectiveness between program planning and implementation. Product
Evaluation is intended for information about results and decision-making to make periodic improvements. While the data collection techniques were obtained through interviews, observation, documentation and questionnaires. The data analysis technique of this research was triangulation of sources, techniques and time. The study was conducted for eleven months in four Community Learning Activity Centers (PKBM) and two Learning Groups (Pokjar) in five Districts in Bogor Regency. The following are the evaluation components and the research instruments table of specification (Table 1).

\section{Evaluation Criteria}

The evaluation criteria are sourced from the Keaksaraan Usaha Mandiri program guide of the Ministry of Education and Culture of the Republic of Indonesia, literacy education concepts and theories. The Table 2 are the evaluation criteria in this study.

Table 1. Evaluation Components and Research Instruments Table of Specification

\begin{tabular}{|c|c|c|c|c|}
\hline Component & Aspect & Indicator & Data Source & Instrument \\
\hline \multirow[t]{3}{*}{ Context } & Background & $\begin{array}{l}\text { Program area } \\
\text { Education and economic } \\
\text { level of students }\end{array}$ & $\begin{array}{l}\text { Program organiz- } \\
\text { ers, tutors, students, } \\
\text { local neighborhood } \\
\text { association }\end{array}$ & $\begin{array}{l}\text { Interview, } \\
\text { observation and } \\
\text { documentation } \\
\text { guidelines }\end{array}$ \\
\hline & Policy & $\begin{array}{l}\text { Understanding policy } \\
\text { Formulation of institu- } \\
\text { tional policies }\end{array}$ & $\begin{array}{l}\text { Program organizers, } \\
\text { tutors and students }\end{array}$ & $\begin{array}{l}\text { Interview and } \\
\text { documentation } \\
\text { guidelines }\end{array}$ \\
\hline & $\begin{array}{l}\text { Program } \\
\text { Objectives }\end{array}$ & $\begin{array}{l}\text { Understanding the goals } \\
\text { Development of program } \\
\text { objectives }\end{array}$ & $\begin{array}{l}\text { Program organizers, } \\
\text { tutors and students }\end{array}$ & $\begin{array}{l}\text { Interview and } \\
\text { documentation } \\
\text { guidelines }\end{array}$ \\
\hline \multirow[t]{2}{*}{ Input } & Tutor & $\begin{array}{l}\text { Education level } \\
\text { Competence of educators } \\
\text { in non-formal education } \\
\text { Technical business skills } \\
\text { speakers }\end{array}$ & $\begin{array}{l}\text { Program organizers, } \\
\text { tutors and students }\end{array}$ & $\begin{array}{l}\text { Interview } \\
\text { guidelines, ques- } \\
\text { tionnaires and } \\
\text { documentation }\end{array}$ \\
\hline & Students & $\begin{array}{l}\text { Educational and socio- } \\
\text { economic level } \\
\text { Has passed the basic lit- } \\
\text { eracy program }\end{array}$ & $\begin{array}{l}\text { Program organizers, } \\
\text { tutors and students }\end{array}$ & $\begin{array}{l}\text { Interview, } \\
\text { observation and } \\
\text { documentation } \\
\text { guidelines }\end{array}$ \\
\hline \multirow[t]{2}{*}{ Process } & $\begin{array}{l}\text { Learning } \\
\text { Activities }\end{array}$ & $\begin{array}{l}\text { Schedule and learning } \\
\text { time } \\
\text { Andragogy approach } \\
\text { Evaluation of learning }\end{array}$ & $\begin{array}{l}\text { Program organizers, } \\
\text { tutors and students }\end{array}$ & $\begin{array}{l}\text { Interview, obser- } \\
\text { vation, angket } \\
\text { and documenta- } \\
\text { tion guidelines }\end{array}$ \\
\hline & $\begin{array}{l}\text { Business } \\
\text { Skills }\end{array}$ & $\begin{array}{l}\text { Types of business skills } \\
\text { Practice business skills }\end{array}$ & $\begin{array}{l}\text { Program organizers, } \\
\text { tutors and students }\end{array}$ & $\begin{array}{l}\text { Interview, } \\
\text { observation and } \\
\text { documentation } \\
\text { guidelines }\end{array}$ \\
\hline Product & $\begin{array}{l}\text { Learning } \\
\text { Outcomes }\end{array}$ & $\begin{array}{l}\text { Learning outcomes } \\
\text { Student graduation level }\end{array}$ & Tutors and students & $\begin{array}{l}\text { Interview and } \\
\text { documentation } \\
\text { guidelines }\end{array}$ \\
\hline
\end{tabular}


Table 2. Evaluation Criteria for the Keaksaraan Usaha Mandiri Program

\begin{tabular}{|c|c|c|c|}
\hline Component & Aspect & Indicator & Criteria \\
\hline \multirow[t]{3}{*}{ Context } & $\begin{array}{l}\text { Back- } \\
\text { ground }\end{array}$ & $\begin{array}{l}\text { Location of } \\
\text { students } \\
\text { Education and } \\
\text { economic level } \\
\text { of students }\end{array}$ & $\begin{array}{l}\text { Mountainous, densely populated, rural and settlement } \\
\text { areas. } \\
\text { Dense illiteracy, dropping out of school and poor areas. }\end{array}$ \\
\hline & Policy & $\begin{array}{l}\text { Understanding } \\
\text { policy } \\
\text { Formulation } \\
\text { of institutional } \\
\text { policies }\end{array}$ & $\begin{array}{l}\text { Permendikbud No. } 42 \text { of } 2015 \text { concerning Keaksaraann } \\
\text { Usaha Mandiri (KUM). } \\
\text { Commitment of MDGs, Literacy Initiative for Empower- } \\
\text { ment, Education for All. } \\
\text { The organizing agency has a policy formulation on lit- } \\
\text { eracy education. }\end{array}$ \\
\hline & $\begin{array}{l}\text { Pro- } \\
\text { gram } \\
\text { Objec- } \\
\text { tives }\end{array}$ & $\begin{array}{l}\text { Understanding } \\
\text { the goals } \\
\text { Development } \\
\text { of program } \\
\text { objectives }\end{array}$ & $\begin{array}{l}\text { Organizers, tutors and students understand the objectives } \\
\text { of the program } \\
\text { Brazilian non-formal education figures Friere and } \\
\text { Macedo stated that "The potential of literacy for not } \\
\text { only reading the word but also reading the world". The } \\
\text { Organization for Economic Co-operation and Develop- } \\
\text { ment (OECD), a Canadian-based study institute, con- } \\
\text { ducted a study and produced a conclusion that "The } \\
\text { ability to understand and employ printed information in } \\
\text { daily activities, at home, at work and in the community-to } \\
\text { achieve ones goals, and to develop ones knowledge and } \\
\text { potential". } \\
\text { Institutions develop goals based on characteristics, local } \\
\text { potential and the needs of students. }\end{array}$ \\
\hline \multirow[t]{2}{*}{ Input } & Tutor & $\begin{array}{l}\text { Education } \\
\text { level } \\
\text { Competence } \\
\text { of educators } \\
\text { in non-formal } \\
\text { education }\end{array}$ & $\begin{array}{l}\text { Minimum high school graduate/ equivalent. } \\
\text { Local community. } \\
\text { Educators are as facilitators who can help students to } \\
\text { meet higher needs. Educators in non-formal education } \\
\text { must have the characteristics of "have a sense of self- } \\
\text { confidence, informality, enthusiasm, responsiveness and } \\
\text { creativity". Apps confirm that non-formal educators } \\
\text { "interest in students, possessed good personalities, have } \\
\text { an interest in the subject matter". }\end{array}$ \\
\hline & $\begin{array}{l}\text { Stu- } \\
\text { dents }\end{array}$ & $\begin{array}{l}\text { Educational } \\
\text { and socio-eco- } \\
\text { nomic level } \\
\text { Has passed the } \\
\text { basic literacy } \\
\text { program }\end{array}$ & $\begin{array}{l}\text { Residents of the local area. } \\
\text { Educational background is not in school or dropped out } \\
\text { of school. } \\
\text { Has attended a basic literacy education program. }\end{array}$ \\
\hline
\end{tabular}

\section{RESULTS AND DISCUSSION}

\section{Context Components}

An evaluation of the context component is carried out to determine the suitability of the background, policies and program objectives. The independent business literacy program is implemented in rural, densely populated and mountainous areas. The three regions are included in the area of dense illiteracy, more than 5000 residents have low levels of family economic in- come. Based on observations and interviews in five research locations, it shows that these areas have the potential for natural resources that can be developed into a source of family economic income. This can be developed into independent business skills of KUM program students. In PKBM Prima Lestari, Pokjar Batu Tulis and Pokjar Curug Bitung have the opportunity to develop businesses in the types of vegetable farming, processed fruits and various other agricultural products. PKBM is also called Community 
Andang Heryahya et al. / Journal of Nonformal Education 6 (1) (2020) 9-18

\begin{tabular}{|c|c|c|c|}
\hline \multirow[t]{2}{*}{ Process } & $\begin{array}{l}\text { Learn- } \\
\text { ing } \\
\text { Activi- } \\
\text { ties }\end{array}$ & $\begin{array}{l}\text { Schedule and } \\
\text { learning time } \\
\text { Andragogy } \\
\text { approach } \\
\text { Evaluation of } \\
\text { learning }\end{array}$ & $\begin{array}{l}\text { The learning approach uses andragogy education. (1) } \\
\text { Establish a physical and psychological climate conducive } \\
\text { to learning (2) Involve learners in mutual planning of } \\
\text { methods and curricular directions (3) Involve participants } \\
\text { in diagnosing their own learning needs (4) Encourage } \\
\text { learners to identify resources and to devise strategies for } \\
\text { using such resources to accomplish their objectives (5) } \\
\text { Encourage learners to formulate their own learning objec- } \\
\text { tives (6) Help learners to carry out their learning plans ( } 7 \text { ) } \\
\text { Involve learners in evaluating their learning. } \\
\text { Non-formal learning focuses on individual learning meth- } \\
\text { ods, group learning methods, and community learning } \\
\text { methods or community development methods. } \\
\text { Learning runs for three months with a minimum of } 86 \\
\text { hours @ } 60 \text { minutes. } \\
\text { The evaluation question is in accordance with the provi- } \\
\text { sions of Permendikbud No. } 42 \text { of } 2015 \text {. }\end{array}$ \\
\hline & $\begin{array}{l}\text { Busi- } \\
\text { ness } \\
\text { Skills }\end{array}$ & $\begin{array}{l}\text { Types of busi- } \\
\text { ness skills } \\
\text { Practice busi- } \\
\text { ness skills }\end{array}$ & $\begin{array}{l}\text { Types of business skills according to the needs of stu- } \\
\text { dents. } \\
\text { Business skills learning activities. }\end{array}$ \\
\hline Product & $\begin{array}{l}\text { Learn- } \\
\text { ing } \\
\text { Out- } \\
\text { comes }\end{array}$ & $\begin{array}{l}\text { Learning out- } \\
\text { comes } \\
\text { Student gradu- } \\
\text { ation level }\end{array}$ & $\begin{array}{l}\text { Minimum exam scores are } 56 \\
\text { At least } 80 \% \text { of participants have passed }\end{array}$ \\
\hline
\end{tabular}

leaning centers are educational institutions that are managed by the community to meet the needs of the community (Syuraini \& Yolanda, 2019). In PKBM Al Hikmah, PKBM Darma and PKBM Pelita Ilmu have business opportunities in managing cassava flour, coconut, ornamental fish livestock and developing snacks such as cassava and banana chips.

PKBM Al Hikmah is located in Ciseeng District, one of the largest ornamental fish producing areas in Bogor. Megamendung District is one of the centers of vegetable and fruit growers. The rural and mountainous regions have the opportunity to build and sustain the people's economy. Therefore, education in rural areas needs to insert practical and technical skills that are in line with the potential of the local environment. Education that can prepare rural communities to participate in regional development (Ministry of Education and Culture, 2017). This integration of learning can explore the potential of the region while providing solutions to the economic development of rural communities.

In many countries, as a result of the Organization for Economic Co-operation and Development (OECD) research Literacy in the Information Age states that Literacy proficiency also has a substantial effect on earnings in many of the countries studied. The effect of literacy skills on earnings depends in part on difference, in levels of education, but in many countries literacy also has an independent, net effect on wages (OECD $\&$ Statistic Canada, 2000). Literacy has a large influence on income in many countries. Education and work skills can be a solution to the poverty that occurs (Alia, et al., 2015). Literacy and entrepreneurship are the main forces to reduce poverty. The higher the level of literacy in a person, the higher the chance of getting the opportunity to be independent and achieve a more decent life.

The environmental potential in the five regions has opportunities to be developed, especially supported by tutors' understanding of the economic potential that exists in each region. In addition, the commitment of the organizers and tutors towards the development of literacy education is quite good. I have worked in several companies, but for me community education is the right place for us to serve and give the best for the community (Didin, 2018). I have fallen in love with public education, who else if not us (Dedih, 2018). This commitment and understanding are in line with the government's ideas in eradicating illiteracy and poverty, MDGs' commitment, Initiative Literacy for Empowerment and Education for All. This awareness was part of the background of the organizing agencies in implementing the IBL program. 
The KUM education program has also been responded well by the students, because there is integration between literacy and business skills. I prefer to learn KUM, because there are skills to make food and other pastries, compared to before in the basic literacy program (Kesih, 2018). Even for some students this program can be an opportunity for self-actualization. In Pokjar Batu Tulis, students not only learn literacy and skills, but actively participate in various activities in the community. Performed in arts and cultural performances on the anniversary of Independence Day and literacy competitions organized by the Bogor District Education Office. Abdi bungah, tiasa ngiring lomba keaksaraan di Dinas Pendidikan, abdi ngiringan sakanteunan jualan kue rangginang. Pesertana seer pisan, alhamdulillah Pokjar Batu Tulis juara kahiji lomba menulis sareung juara ke tilu lomba mengarang. I am happy, being able to take part in the literacy competition at the Education Office, I came to sell all the rangginang cakes. Lots of participants, Alhamdulillah Pokjar Batu Tulis won first place in the writing competition and third place in the story writing competition (Pipin, 2018). This achievement is inseparable from the role of tutors whose daily lives are active as community mobilizers in the village administration, both in Family Welfare Empowerment and in Early Childhood Development (PAUD). We not only learned to read and write, but were always active in the community, we all performed in literacy competitions at the office, performing arts and walking in the commemoration of Independence Day. Students can be mobilized, depending on our enthusiasm (Neneng, 2018).

Research findings in this component confirm that illiterate people have the opportunity and potential to develop and contribute to the economic development of the village. Likewise, with the organizers and tutors, they are committed to the development of literacy education and a good understanding of the development of the village economic potential.

\section{Input Components}

Evaluation on the input component is carried out to determine the suitability of the tutor and students. The results of this study indicate that the tutor's work background is mostly as elementary school teachers, then village activists and local community leaders. As many as $75 \%$ of tutors have had teaching experience for literacy education with an average of more than three years. Administratively, all tutors have fulfilled the requirements as program guidelines. All tutors have undergraduate and/or high school edu- cation background. As many as $65 \%$ of tutors have participated in literacy training both organized by the Bogor District Education Office and the Ministry of Education and Culture.

All tutors live in the same area with the students, one village, one language and one culture. Tutor recruitment patterns mostly through family channels, friendships with fellow teachers and involvement of local religious leaders. The pattern of recruitment through the family path seems to be more dominant compared to other approaches, for example involving village youths. My sister has good competence and exceptions to community education, including early childhood education (Neneng, Chairperson of Curug Bitung Pokjar). I have many teacher friends at school, knowing their character and personality including their competence, they are worthy to accompany students (Dedih, Chairperson of PKBM Prima Lestari). We always invite the wife of Neighborhood Association's leader and local community leaders. They are closer to the community, so they can help move students (Luru, Chairperson of PKBM Pelita Ilmu).

When viewed from the aspect of tutor characteristics as educators in non-formal education, it can be seen from six aspects, namely self-confidence, communication skills, interest in non-formal education, attention to students, responsive and creative. The results of the study can be seen in the Figure 1.

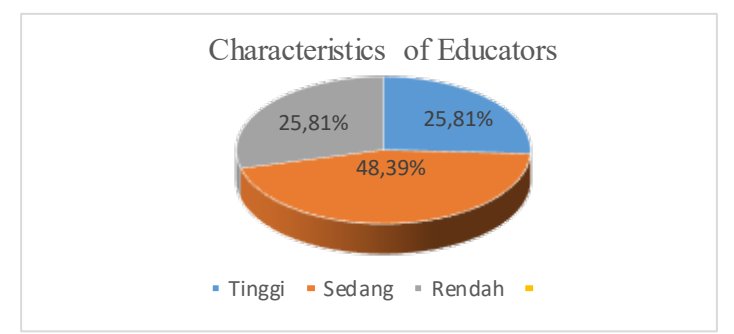

Figure 1. Characteristics of Educators Non-formal education

The characteristics of pedagogue as educators in non-formal education are quite visible in the aspects of communication and self-confidence. Meanwhile, aspects of attention to students and creativity tend to be low. This condition occurs because the experience and age of some tutors is relatively young, compared to the age of the students. I sometimes hesitate to communicate with students, given their age is much older than me (Vina, tutor Pokjar Curug Bitung, 2018). Another factor is the lack of learning facilities and infrastructure. Learning activities using only a mat, a small size blackboard, limited study spa- 
ce with an average of 3 times 4 square meters. In the aspect of attention to students, most tutors do not utilize daily interactions as part of mentoring. Activities in the rice fields, fields, markets and in various other forms of interaction are not utilized to care for and preserve the literacy of students.

Whereas on the other hand tutors reside in the same area with students using the same language and culture. This condition should be able to be a part of mentoring efforts for students. This is in line with research by (Nigel, et al., 2013) that local native educators are seen to be more effective because they are involved in cultural and linguistic processes with students (Poole, et al., 2013). Moreover, tutors are an important part in the learning process. The common denominator in school improvement and student success is the teacher (Stronge, et al., 2011). Tutors are one of the factors that determine the level of learning success of students.

While all students are adult women aged between 35 to 60 years. The background of students is school dropout, housewives and most work as laborers. The main cause of illiteracy due to limited economic income of the family, then becomes the cause of the short mindset of the people that is, earning money even though they have to be manual labor. Rek saha anu ngabiayaan sakola kan perlu biaya. Jaman kapungkurmah yang penting tiasa maca sareung nulis teu kedah lulus SD. Who wants to provide funding, the school needs funds? In the past it was important to be able to read and write, didn't need to graduate elementary school (Imas, PKBM Darma Students).

Initially there were male students but over time, they did not attend the program anymore. Male students tend to be more difficult to organize because of job characteristics and types of skills that require a larger budget. Pamegeutmah mah hararese, eraan sareng sibuk di sawah di kebon, Men are difficult to manage, they may be shy and have a lot of work (Dedeh, 2018). Pamegeutmah pan keterampilana oge butuh biaya ageung, myuhunkeun usaha ternak. Men are difficult to organize, shy and busy with their work in the fields and gardens. Requires skills at great expense, they ask to learn to raise livestock (Dedeh, 2018). However, the eradication of illiteracy through women is very important (Agee, 2005). Useful for breaking the illiterate chain and developing children's intelligence. Mothers are seen as able to transmit reading skills in the smallest level of social institutions, namely the family.

Mothers can transmit literacy to children from the time of pregnancy and breastfeeding. The closeness of a mother to a child can be a ma- jor factor to ensure literacy occurs starting from early childhood. Literacy is proven to improve the level of life, especially for women (Akello, et al., 2017). Literacy can help women to be more developed and successful in the contemporary world. Investment in women's education, including literacy is considered one of the most important elements, which complements the activities of producing some women who are considered important for women's economic (Preethi, 2015).

However, this study shows that tutors' entrepreneurial experience and competencies tend to be inadequate. The tutors have no background as entrepreneurs. Then it does not appear that there are entrepreneurs in the local environment who participate in teaching business skills to students. So, entrepreneur skill learning is not running optimally.

\section{Process Components}

The process component is carried out to find out the implementation of learning. The results of this study indicate that the learning process carried out for three months, in some institutions carried out for four months is equivalent to 86 hours. The program is carried out twice a week with an average length of study of two hours. Based on observations and interviews, learning schedules often experience changes, both in terms of days and time. Changes to the schedule are evenly distributed across all organizing agencies, except in PKBM Al Hikmah and PKBM Pelita Ilmu. On several occasions, I went to the homes of the students to pick them up directly, visited the house one by one reminding and invited to attend learning (Yayah, 2018). Then the institute provides funding subsidies for pilgrimage trips to historical places such as Wali Songo and Pamijahan Tasikmalaya. In these two institutions there were not many schedule changes. Learning is carried out simultaneously with the majelis taklim schedule.

Participation of students in attending majelis taklim looks better than just take part in the literacy program. Learning schedules that are integrated with majelis taklim can increase student attendance. Although not all pilgrims are registered as students, but turn out it can provide benefits to a more dynamic learning atmosphere and it can help each other. Majelis taklim pilgrims can mingle with students. Indirectly, women of Quran recitation group can function as a source of learning. Such participation can be seen in the practice of writing skills and activities. They help and cooperate with each other, with an atmosphere filled with intimacy. 
The findings of this study indicate that, building one's individual will be more effective if carried out in an integrated manner between social, spiritual and economic needs and even sensitive to ecological and environmental development (Lyz \& Opryshko, 2016). This is in line with the idea of critical literacy, which emphasizes reading in a broader sense and is capable of empowering and analyzing social transformation (Janks, 2017). Literacy education can build the strength of economic independence and social awareness as well as able to do analysis in social transformation.

In PKBM Darma, Pokjar Curug Bitung and PKBM Prima Lestari the implementation of the program in conjunction with harvesting activities in the fields. Abdi pasti angkat ka sawah, kumargi panen te tiasa ditunda. I chose to go to the fields because the rice harvest could not be postponed (Acah, 2018). In addition to activities in the fields, other factors include parenting, attending family or neighbors' weddings, caring for sick children and other activities in the family and community. Frequent changes in study schedules causes the attendance of students to be low. I sometimes go home first to see my child who's sleeping, or cook rice and side dishes, then come back to study again (Cicih, Student PKBM Pelita Ilmu, 2018).

While on the other hand, reading, writing and arithmetic activities require regular practice to prevent forgetting and stagnation (Agee, 2005). The involvement of students in the learning program can be recognized as the experience they have can make a positive contribution to the learning process (Rothes, et al., 2017). Andragogy competence and tutor perseverance are needed in accompanying learners.

The implementation of learning in all organizing institutions is filled with the practice of making various kinds of cakes and other similar foods. Upami teu aya praktek ngadameul kue peserta didik sesah kempel, namung lami-lami ieu abdi tiasa rugi kumargi anggaran terbatas. If there is no baking activity, the community will be difficult to attend, we will eventually suffer losses due to limited budget (Dini tutor Pokjar Curug Bitung, 2018). The selection of this type of skill is the result of an agreement between the tutor and students, taking into account the availability of the budget and the economic potential that exists in each region. This condition is because the organizing agency does not have other funding sources, other than assistance from the Directorate of Community Education, Ministry of Education and Culture of the Republic of Indonesia.
Although the practice of business skills was more widely studied, the material on the introduction of product packaging and marketing strategies was not taught. No tutor had a background as an entrepreneur or had a similar business. The involvement of the business world was also not seen in this literacy learning process. Both of these are one of the factors why the material regarding packaging and marketing strategies is not optimally conveyed. Then on the other hand, students also lack good motivation to do business. Abdimah tos kolot moal jualan, keun bae engke pura putra abdi mudah mudahan aya anu tiasa icalan. I am old, there is no interest in selling, but God willing, my children or grandchildren who will do business, (Enjam, PKBM Darma students, 2018). Because of age, some students tend to continue to pursue the profession as housewives, working as usual in the rice fields and fields.

While in the aspect of literacy education, time allocation is widely used for reading and writing activities. Arithmetic activities are hardly taught to students. Various recipes and ways to make various cakes are seen recorded by the tutor on the board, then followed by students. Students are given the opportunity to take turns writing on the board. The process of calculating production costs and estimating business profits is not much done. The learning process in general focuses more on skills practice then writing and reading activities.

In the aspect of using andragogy learning principles in general have been applied by tutors. Below are the results of research into the application of andragogy using six indicators, namely:

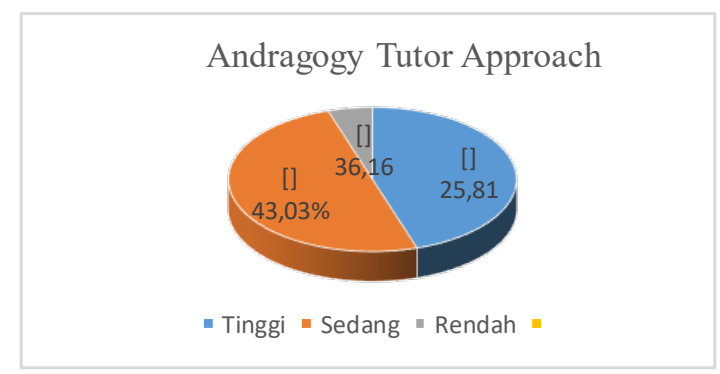

Figure 2. Andragogy Tutor Approach

The lowest value is found in the aspects of student involvement in evaluation, identification of learning needs, learning as problem solving and the use of learning media. In non-formal education, learning should begin with identifying the problem first. Developing a learning program based on activities and abilities, and based on community needs and experiences is the main task of the tutor (Jarvis, 1992). Meanwhile, high 
scores are found in aspects of creating a learning climate, creating a learning atmosphere that helps each other and optimizes experiences as learning resources. The experience and educational background of tutors as community activists and local religious leaders contribute to the climate and learning atmosphere. Besides that, the culture of helping one another is still part of the personality of the people in rural areas. This condition is unconsciously carried by tutors and students into the learning process.

\section{Product Components}

Evaluation on product components is carried out to determine student learning outcomes. In all institutions, students were declared to graduate with an Excellent grade of $10.5 \%$, graduated with a Good grade of $80.87 \%$ and graduated with a Fair category of $9.4 \%$. However, the final evaluation questions are prepared by tutors and do not use questions published by the Education Office. Whereas in Permendikbud Number 42 Year 2015 the final evaluation of ILB Education is carried out by the local Education Office.

On the other hand, there are no students who utilize or continue the business skills learned in their daily activities. This condition can potentially make illiterate students return to the way they were and cause them to lose the chance to be independent. However, as a matter of fact independence and the moral development of society are interrelated with one another (Lyz \& Opryshko, 2016). Learning should have an impact on improving the process of building community life. Individual experience in literacy can meet the needs of work practice or a willingness to improve reading skills can accelerate independence to obtain value and knowledge (Agee, 2005). Building human resources to lead or change lives that are independent and empowered than before, UNESCO emphasized "Being literate adds value to a person's life. Literacy can be instrumental in the pursuit of development - at personal, family and community levels, as well as at macro-levels of nations, regions and the world" (UNESCO, 2015).

In the end, literacy can benefit individuals, families and society altogether. Literacy can increase participation in life starting from the smallest area to a broader level. It can also limit population growth, reduce poverty, prevent maternal and child mortality, ensure sustainable development, peace and democracy (Hidayati, 2013). Literacy is at the heart of education and improving the quality of life of families and communities.

\section{CONCLUSIONS}

The Keaksaraan Usaha Mandiri (KUM) education program is implemented in a dense illiterate region with all students being women. The main factor of students experiencing illiteracy is because of the low economic income of the family which affects the way of thinking of the community to be short, with the perception that what is important is to make money even though they have to be manual laborers. Male students have not been well facilitated because of the busyness and interests of skills that are different from female students. In addition, budget limitations cannot reach the skills needed by prospective male students.

Learning that is integrated with majelis taklim makes the level of attendance of students is much higher compared to just learning literacy. While in the aspect of learning outcomes, it has not been able to reflect the literacy competencies of students, because the question scripts used do not meet the standards as Permendikbud Number 42 of 2014.

\section{REFERENCES}

Adepoju, A. O., \& Akinluyi, O. I. (2017). Multidimensional Poverty Status of Rural Households in Nigeria: Does family planning have any effect? International Journal of Social Economics, 44(8), 1046-1061.

Agee, J. (2005). Literacy, aliteracy, and lifelong learning. New Library World, 106(5/6), 244-252. https://doi.org/10.1108/03074800510595850

Akello, J. A., Lutwama-Rukundo, E., \& Musiimenta, P. (2017). Functional Adult Literacy: An Alternative Gateway to Grassroots Women's Improved Income Generation in Lango Subregion, Northern Uganda. Adult Education Quarterly, 67(2), 79-96. https://doi. org/10.1177/0741713616685143

Alia, D. Y., Alia, K. A. S. M. J.-J., \& Fiamohe, E. R. (2015). On poverty and the persistence of poverty in Benin. Journal of Economic Studies, 43(4), 661-676.

Arbarini, M., Jutmini, S., \& Joyoatmojo, S. (2018). Effect of Participatory Learning Model on Functional Literacy Education. Journal of Nonformal Education, 4(1), 13-24. https://doi. org/10.15294/jne.v4i1.13570

Badan Pusat Statistik. (2019). Statistik Indonesia: Statistik Yearbook of Indonesia 2019 (Subdirektorat Publikasi dan Kompilasi Statistik, Ed.). Jakarta: Badan Pusat Statistik.

Echols, J. M., \& Shadily, H. (2000). Kamus Inggris Indonesia. Jakarta: PT Gramedia Pustaka.

Hidayati, I. (2013). Literasi, Hak Asasi Yang (nyaris) Terlupakan. 
Istiqomah, N., \& Articles, I. (2017). Evaluasi Mutu Layanan Pendidikan Kesetaraan pada PKBM Citra Ilmu di Semarang. Journal of Nonformal Education, 3(2), 149-157. https://doi. org/10.15294/jne.v3i2.10950

Janks, H. (2017). Critical literacy and the social justice project of education. Jurnal English Teaching: Practice \& Critique, 16(2), 132-144.

Jarvis, P. (1992). Adult and Conditioning Education. London: Croom Helm.

Kolawole, O. D., \& Ajila, K. (2015). Driving local community transformation through participatory rural entrepreneurship development. World Journal of Entrepreneurship, Management and Sustainable Development, 11(2), 131-139. https:// doi.org/10.1108/wjemsd-06-2014-0016

Laksono, B. A., Supriyono, S., \& Wahyuni, S. (2018). Perception of Illiterate Society Toward The Functional Literacy Program. Journal of Nonformal Education, 4(2), 131-140. https://doi. org/10.15294/jne.v4i2.16003

Lyz, N., \& Opryshko, A. (2016). Life-creating education: new educational meanings in modern world. On the Horizon, 24(4), 377-386. https:// doi.org/10.1108/OTH-06-2016-0028

Mazumdar, K. (2005). Socio-economic factors determining adult literacy in developing countries. International Journal of Social Economics, 32(1/2), 98-120. https://doi. org/10.1108/03068290510575667

Ministry of Education and Culture. (2017). No Title.

Nigel, P., Fernando, Á., Nora, P., \& Roberto, V. (2013). Education for all and for what? Lifeskills and livelihoods in rural communities. Journal of Agribusiness in Developing and Emerging Economies, 3(1), 64-78. https://doi. org/10.1108/20440831311321656

OECD, \& Statistic Canada. (2000). Literacy in the Information Age. Paris.

Owen, J. M. (1993). Evaluation Program: Forms and Ap- proaches (St. Leonar). Allen \& Unwin Pty Ltd.

Poole, N., Álvarez, F., Penagos, N., \& Vázquez, R. (2013). Education for all and for what? Life-skills and livelihoods in rural communities. Journal of Agribusiness in Developing and Emerging Economies, 3(1), 64-78. https://doi. org/10.1108/20440831311321656

Preethi, K. A. (2015). Education and Economic Empowerment of Women. Education \& Economic Empowerment of Women, 5(1), 32-45.

Rahma, R. A. (2019). The Role of Community Learning Center (CLC) in Providing Nonformal Education Services Based on Entrepreneurship. Journal of Nonformal Education, 5(2), 109-116. https://doi.org/10.15294/jne.v5i2.19759

Rothes, A., Lemos, M. S., \& Gonçalves, T. (2017). Motivational Profiles of Adult Learners. Adult Education Quarterly, 67(1), 3-29. https://doi. org/10.1177/0741713616669588

Spaulding, D. T. (2008). Program Evaluation in Practice. San Francisco: John Wiley.

Stronge, J. H., Ward, T. J., \& Grant, L. W. (2011). What Makes Good Teachers Good? A Cross-Case Analysis of the Connection Between Teacher Effectiveness and Student Achievement. Journal of Teacher Education, 62(4), 339-355. https://doi.org/10.1177/0022487111404241

Stufflebeam, D. L., \& Shinkfield, A. J. (1984). Systematic Evaluation : a Self-Instructional Guide to Theory and Practice. Springer Netherlands.

Syuraini, S., \& Yolanda, Y. (2019). Overview of Learning Evaluation in Entrepreneurship Subjects Equality Education Paket C. Journal of Nonformal Education, 5(2), 203-208. https://doi. org/10.24036/kolokium-pls.v7i1.18

UNESCO, U. (2015). World declaration on education for all-Meeting basic learning needs.

Worthen, B. R., \& Sanders, J. R. (1973). Educational evaluation: theory and practice. Wadsworth Pub. Co. 